\title{
EFFECTS OF FEEDING SNAILS WITH PINEAPPLE WASTE ON FEED CONSUMPTION, GROWTH AND COST BENEFITS
}

\author{
EFECTO DE LA ALIMENTACIÓN DE CARACOLES CON DESPERDICIO DE PIÑA \\ SOBRE EL CONSUMO DE ALIMENTO, CRECIMIENTO, COSTES Y BENEFICIOS
}

Omole, A.J. ${ }^{1}$, Ajasin, F.O. ${ }^{2}$, Adejuyigbe, A.D. ${ }^{2}$ and Soetan, A. ${ }^{3}$

${ }^{1}$ Obafemi Awolowo University. Institute of Agricultural Research and Training. Ibadan. Nigeria. ${ }^{2}$ Federal College of Animal Health and Production Technology, I.A.R.\&T. Ibadan. Nigeria. ${ }^{3}$ Department of Veterinary Medicine. University of Ibadan. Nigeria.

\author{
AdDITIONAL KEYWORDS \\ Growth. Archachatina marginata. Dressing.
}

\section{SUMMARY}

The effect of inclusion of $0,5,10$, and $15 \%$ of pineapple waste (PW) in the diet of growing snails (Archachatina marginata), on feed consumption, growth, dressing percentage and cost benefits was studied. Each treatment was replicated thrice with 7 snails per replicate in a completely randomized design. Variables studied were: feed intake, weight gain, shell length and width, feed conversion ratio and cost per weight gain. The weight gain until $10 \%$ level of inclusion compared favourably with the control diet. The feed conversion ratio was similar, respect to control, at all levels of inclusion. The feed intake reduced as the level of PW increased $(p<0.05)$. The shell length and width were not affected by varying PW level. The dressing percent at 0,5 and $10 \%$ levels of inclusion were not influenced by treatments. The cost/weight gain reduced as level of inclusion of PW increased in the diet. Pineapple waste could be included up to $10 \%$ in the diet of growing snails.

\section{RESUMEN}

Se estudió el efecto de la inclusión de 0,5,10, y $15 \%$ de residuos de piña (PW) en la dieta de caracoles en crecimiento (Archachatina marginata), sobre el consumo de alimento, crecimiento, porcentaje de faenado y coste-beneficio. Se realizaron 3 repeticiones con 7 caracoles por repetición en un diseño completamente al azar. Se estudió la ingestión de alimento, ganancia de peso, longitud y ancho de la concha, índice de conver-

\author{
Palabras ClaVe adicionales \\ Crecimiento. Archachatina marginata. Faenado.
}

sión de alimento y coste de la ganacia de peso. La ganancia de peso con inclusión de hasta el 10\% de PW fue similar a la de la dieta control. El índice de conversión de alimento en todos los niveles fue similar al del control. La ingestión de alimento se redujo al aumentar el PW $(p<0,05)$. El tamaño de la concha no fue afectado al variar el nivel de PW y tampoco el porcentaje en faenado a los niveles de 0,5 y $10 \%$. El coste de la ganancia de peso se redujo a medida que se incrementaba el PW. El residuo de piña puede incluirse hasta el $10 \%$.

\section{INTRODUCTION}

Snails are highly appreciated in many African countries for its high nutritive and medicinal values. They are low in $\mathrm{Na}$, fat and cholesterol but also contain high contents of $\mathrm{Fe}$ and $\mathrm{Ca}$; hence they are useful in the treatment of anemia and hypertension (Cobbinah, 1993; Amusan et al., 1998; Ejidike, 2001). The high cost and scarcity of some feed ingredients have been the most limitant factor for commercial livestock production in Nigeria coupled with mananimal competition for grains like maize. Formulated diet can be given to snails to enhance growth and laying performance but the cost of producing the feed is quite expensive because of high cost of feed 
ingredients such as maize, wheat offal and corn-bran which are sources of energy. In order to reduce the cost of the feed, there is need to look for alternative sources which are affordable and available. Pineapple waste is a by-product from agro-processing industry. It is a waste, dump in the bush or along highways in Nigeria. Dumping of the waste in the bush, if not utilized by animals or converted to other useful purposes, could lead to environmental pollution. Ruminant such as sheep, goat and cattle fed on pineapple waste without any adverse effect. As of present there is no information on the utilization of pineapple waste by snails hence this study was designed to determine the effect of feeding the snails on varying level of pineapple waste in the diet of growing snails on growth, dressing percentage and cost benefits.

\section{MATERIAL AND METHODS}

The trial was conducted at the snailery unit of the Institute of Agricultural Research and Training Moor Plantation, Ibadan, Oyo state. A total of 84 growing snail (Archachatina marginata) of about 4 months of age of relatively the same size of mean weight of $86.78 \pm 5 \mathrm{~g}$ with no shell damage were randomly selected and allotted to 4 dietary treatments. Each treatment was replicated thrice with seven snails per replicate in a completely randomized design. Four diets were formulated to contain $0 \%\left(\mathrm{~T}_{1}\right), 5 \%\left(\mathrm{~T}_{2}\right)$, $10 \%\left(\mathrm{~T}_{3}\right)$, and $15 \%\left(\mathrm{~T}_{4}\right)$ dry pineapple waste and all contained about $24 \%$ crude protein and energy of 2500-2600 kcalME/kg (table I). The pineapple waste was collected at Fumman Agro-Industry located at Apata, Ibadan, Oyo State, Nigeria. Pineapple waste is a by-product after pressing the peeled ripe pineapple by hydraulic press to fruit juice. The remaining solid portion is the pineapple waste. It was then sun-dried before incorporating with other feed ingredients. The snails were reared in a wooden cage of 12 compartments and each compartment had a dimension of $0.5 \times 0.5 \times$ $0.5 \mathrm{~m}^{3}$. The top of the cage was covered with mosquito net reinforced with wire netting. The parameters measured were feed intake and weight gain on daily and weekly basis respectively. The shell length and width were measured with vernier caliper on weekly basis. Feed conversion ratio and feed cost were calculated. At the end of the feeding trial twelve snails were randomly selected from each treatment, starved overnight in order to remove remnants feed from the gut. The snails were weighed separately and the shell were later broken with iron rod. The shell, viscerals, and the feet (edible portion) were weighed. The chemical composition of the experimental diets was carried out according to the method of AOAC (1990). All data were subjected to statistical analysis of variance and the means were separated using Duncan Multiple range test (SAS, 1995).

\section{RESULTSANDDISCUSSION}

The result of the chemical composition of pineapple waste is shown in table I. It could be observed that pineapple waste contained low protein content of $2.38 \%$ with fibre level of $11.4 \%$. The fat content was low

Table I. Chemical composition of the pineapple waste $(P W)$ and experimental diets (\% dry matter basis). (Composición química del desperdicio de piña (PW) y las dietas experimentales (\%, sobre materia seca)).

\begin{tabular}{lccccc}
\hline & $\mathrm{PW}$ & $\mathrm{T}_{1}$ & $\mathrm{~T}_{2}$ & $\mathrm{~T}_{3}$ & $\mathrm{~T}_{4}$ \\
\hline $\mathrm{DM}$ & 92.34 & 94.28 & 93.27 & 94.15 & 92.78 \\
$\mathrm{CP}$ & 4.38 & 23.2 & 23.04 & 22.26 & 22.49 \\
EE & 11.4 & 4.56 & 4.52 & 4.45 & 4.44 \\
CF & 1.38 & 10.91 & 11.21 & 12.06 & 12.68 \\
Ash & 6.38 & 6.86 & 7.28 & 7.69 & 8.01 \\
NFE & 76.46 & 54.25 & 53.95 & 53.01 & 52.38 \\
\hline
\end{tabular}

$\mathrm{DM}=$ Dry matter; $\mathrm{CP}=$ Crude protein; $\mathrm{EE}=\mathrm{Ether}$ extract; $\mathrm{CF}=$ Crude fiber; $\mathrm{NFE}=$ Nitrogen free extract. 
Table II. Summary of performance characteristics of growing snail fed varying level of dry pineapple waste. (Resumen de las características productivas de caracoles en crecimiento alimentados con residuo deshidratado de piña).

\begin{tabular}{lccccc}
\hline Parameters (mean values) & $\mathrm{T}_{1}$ & $\mathrm{~T}_{2}$ & $\mathrm{~T}_{3}$ & $\mathrm{~T}_{4}$ & \pm SEM \\
\hline Initial weight $(\mathrm{g})$ & $87.45^{\mathrm{a}}$ & $86.15^{\mathrm{a}}$ & $87.02^{\mathrm{a}}$ & $85.9^{\mathrm{a}}$ & 4.89 \\
Final weight $(\mathrm{g})$ & $387.4^{\mathrm{a}}$ & $383.34^{\mathrm{a}}$ & $380.12^{\mathrm{a}}$ & $339.15^{\mathrm{b}}$ & 14.8 \\
Weight gain $(\mathrm{g})$ & $299.95^{\mathrm{a}}$ & $297.19^{\mathrm{a}}$ & $293.9^{\mathrm{a}}$ & $253.25^{\mathrm{b}}$ & 11.23 \\
Monthly weight $(\mathrm{g})$ & $74.99^{\mathrm{a}}$ & $74.30^{\mathrm{a}}$ & $74.28^{\mathrm{a}}$ & $63.31^{\mathrm{c}}$ & 4.15 \\
Total feed intake $(\mathrm{g})$ & $1003.8^{\mathrm{a}}$ & $968.24^{\mathrm{a}}$ & $772.4^{\mathrm{b}}$ & $613.2^{\mathrm{c}}$ & 39.2 \\
Monthly feed intake $(\mathrm{g})$ & $250.95^{\mathrm{a}}$ & $242.06^{\mathrm{a}}$ & $234.64^{\mathrm{ba}}$ & $226.4^{\mathrm{b}}$ & 12.5 \\
Feed conversion ratio & $3.35^{\mathrm{ab}}$ & $3.25^{\mathrm{b}}$ & $3.15^{\mathrm{b}}$ & $3.57^{\mathrm{a}}$ & 0.42 \\
Monthly shell increment (mm) & $10.42^{\mathrm{a}}$ & $10.41^{\mathrm{a}}$ & $10.38^{\mathrm{a}}$ & $9.98^{\mathrm{a}}$ & 0.61 \\
Monthly shell with increment & $8.68^{\mathrm{a}}$ & $8.64^{\mathrm{a}}$ & $8.59^{\mathrm{a}}$ & $8.46^{\mathrm{a}}$ & 0.5 \\
Mortality & 0 & 0 & 0 & 0 &
\end{tabular}

Means along rows with different superscript are significantly different from each other $(p<0.05)$.

but rich in ash content. Pineapple waste could be used as source of fibre. The crude protein, ether extract and crude fibre content of the experimental diets (table I) fell within the recommended values (Omole, 2003). There were no significant differences in the mean monthly weight gain of the snails in the control diet and $10 \%$ inclusion of pineapple waste $(p>0.05)$ (table II) but the mean monthly weight gain in the control diet was higher than that of $15 \%$ inclusion $\left(\mathrm{T}_{4}\right)$. The mean monthly feed intake followed the same trend with hat of the weight gain. The low performance recorded in $\mathrm{T}_{4}$ could be due to high level of pineapple waste in the diet. Moreover, the crude protein of the control diet was slightly higher than that of $\mathrm{T}_{4}$ and it has been reported that the performance of snail is enhanced with high protein content in the diet (Bright, 1996), however, the weight gain recorded in $\mathrm{T}_{1}, \mathrm{~T}_{2}$ and $\mathrm{T}_{3}$ was similar to the observation of Hamzat (2004) when cocoa bean shell was used to replace maize at $5 \%$ inclusion. The results also indicate that inclusion of pineapple waste up to $10 \%$ did not have any adverse effect on growth performance. The ratio of feed to weight gain (feed conversion ratio) as observed in table II was at the best at $10 \%$ inclusion of pineapple waste i.e. the lowest the figure of feed to weight gain ratio, the better the efficiency of feed utilization thus the snails in $\mathrm{T}_{3}$ efficiently utilized the feed better than others. There were no significant differences in the mean monthly shell length in all the treatments as shown in table III $(p>0.05)$. Dietary treatments had no significant effect on the mean shell width increment. The minerals content of the feed vis-à-vis ash content in all the treatments were relatively the same. No mortality was recorded in the course of the study which

Table III. Cost analysis (mean values) of growing snails fed experimental diets. (Análisis de coste (valores medios) de caracoles en crecimiento alimentados con las dietas experimentales).

\begin{tabular}{lcccc}
\hline & $\mathrm{T}_{1}$ & $\mathrm{~T}_{2}$ & $\mathrm{~T}_{3}$ & $\mathrm{~T}_{4}$ \\
\hline Cost/kg (N) & 43.4 & 42.1 & 40.1 & 38.7 \\
Total feed intake $(\mathrm{kg})$ & 1.00 & 0.968 & 0.724 & 0.613 \\
Total feed cost $(\mathrm{N})$ & 43.4 & 40.75 & 30.97 & 23.72 \\
Weight gain (g) & 0.30 & 0.30 & 0.30 & 0.25 \\
Cost/weight gain (N) & 144.7 & 135.8 & 103.2 & 94.9 \\
\hline 145 Nigerian N= 1 US Dollar. & & &
\end{tabular}


Table IV. Carcass analysis of growing snail fed experimental diet. (Análisis de las canales de caracoles en crecimiento alimentados con las dietas experimentales).

\begin{tabular}{lccccc}
\hline & $T_{1}$ & $T_{2}$ & $T_{3}$ & $T_{4}$ & $\pm S E M$ \\
\hline Live weight $^{1}$ & $386.2^{\mathrm{a}}$ & $383.3^{\mathrm{a}}$ & $379.1^{\mathrm{a}}$ & $331.2^{\mathrm{b}}$ & 15.1 \\
Foot weight $^{1}$ & $162.5^{\mathrm{a}}$ & $160.6^{\mathrm{a}}$ & $156.7^{\mathrm{a}}$ & $127.1^{\mathrm{b}}$ & 8.5 \\
Shell weight $^{1}$ & $97.0^{\mathrm{a}}$ & $96.2^{\mathrm{a}}$ & $91.4^{\mathrm{b}}$ & $76.8^{\mathrm{a}}$ & 5.8 \\
Dressing $^{2}$ & $42.1^{\mathrm{a}}$ & $41.9^{\mathrm{a}}$ & $41.3^{\mathrm{ab}}$ & $38.4^{\mathrm{b}}$ & 2.5 \\
S/LW & $25.1^{\mathrm{a}}$ & $25.1^{\mathrm{a}}$ & $24.1^{\mathrm{ab}}$ & $23.2^{\mathrm{b}}$ & 1.6
\end{tabular}

${ }^{a b}$ In a row, means with different superscript are different $(p<0.05) . S / L W=$ Shell/Live weigh. ${ }^{1}(\mathrm{~g}) ;{ }^{2}(\%)$.

could be as a result of hardy nature of snails, good management practices coupled with the fact that pineapple waste was well processed, preserved and contained no anti-

\section{REFERENCES}

Amusan, J.A., Oluokun, A.J., Ogundola, F.I. and Omole, A.J. 1998. Snail Farming Guide: Technical Bulletin, I.A.R.\& T. Ibadan.

AOAC. 1990. Association of Official Analytical Chemist. Official Methods of Analysis, $13^{\text {th }}$ Edition. Washington, D.C.

Bright, S.O. 1996. Prospects and problems associated with snail farming. Heritage Printers Nig. Ltd. Lagos. 96 pp.

Cobbinah, J.R. 1993. Snail Farming in West Africa. A Practical Guide: C.T.A. Publication. 126 pp.

Ejidike, B.N. 2001. Comparative effect of supplemental and complete diets on the performance of African giant land snail (A. marginata). Procee- nutritional factors (Bright, 1996). The total feed cost reduced from Naira 43.4 in the control diet toNaira $23.72 \mathrm{in}_{4}$ as shown in table III. The cost per weight gain reduced as the level of pineapple waste in the diet increased (Naira 144.67 in $\mathrm{T}_{1}$ toNaira 94.88 in $\mathrm{T}_{4}$ ). The cost per weight gain recorded in $\mathrm{T}_{4}$ indicates that it is profitable and beneficial to include pineapple waste into the diet of snail. The dressing percent at 0,5 and $10 \%$ levels of inclusion were not significantly influenced by dietary treatments $(\mathrm{p}>0.05)$ (table IV).

\section{CONCLUSIONS}

It could be concluded that pineapple waste could be included up to 105 in the diet of growing snails without any adverse effect on feed consumption, growth, feed conversion ratio and dressing percentage but at a reduced cost.

dings of the $26^{\text {th }}$ Annual Conference of the Nigerian Society for Animal Production. Vol. 26. pp. 151-153.

Hamzat, R.A. 2004. Utilization of cocoa bean shell in the diet of growing snail (A. marginata). Ph.D Thesis. Department of Animal science. University of Ibadan. Nigeria.

Omole, A.J. 2003. Nutrient requirement of different classes of snail ( $A$. marginata) at different stages of growth. Ph.D Thesis. Department of Animal Science. University of Ibadan. Nigeria.

SAS. 1995. S.A.S. User's Guide. Statistical Analysis System Institute, Inc. Cary, N.C. 